\title{
Integrated Marketing Strategies and Performance of Hospitality Firms Amidst the COVID-19 Pandemic
}

\section{Glory Sunday Etim, Edim Eka James, Eyo Emmanuel Essien, Victor} Olusegun Okeowo

To Link this Article: http://dx.doi.org/10.6007/IJARBSS/v11-i11/11534

DOI:10.6007/IJARBSS/v11-i11/11534

Received: 15 September 2021, Revised: 20 October 2021, Accepted: 04 November 2021

Published Online: 17 November 2021

In-Text Citation: (Etim et al., 2021)

To Cite this Article: Etim, G. S., James, E. E., Essien, E. E., \& Okeowo, V. O. (2021). Integrated Marketing Strategies and Performance of Hospitality Firms Amidst the COVID-19 Pandemic. International Journal of Academic Research in Business and Social Sciences, 11(1), 2300-2317.

Copyright: (C) 2021 The Author(s)

Published by Human Resource Management Academic Research Society (www.hrmars.com)

This article is published under the Creative Commons Attribution (CC BY 4.0) license. Anyone may reproduce, distribute, translate and create derivative works of this article (for both commercial and non0-commercial purposes), subject to full attribution to the original publication and authors. The full terms of this license may be seen at: http://creativecommons.org/licences/by/4.0/legalcode

Vol. 11, No. 11, 2021, Pg. $2300-2317$

Full Terms \& Conditions of access and use can be found at http://hrmars.com/index.php/pages/detail/publication-ethics 


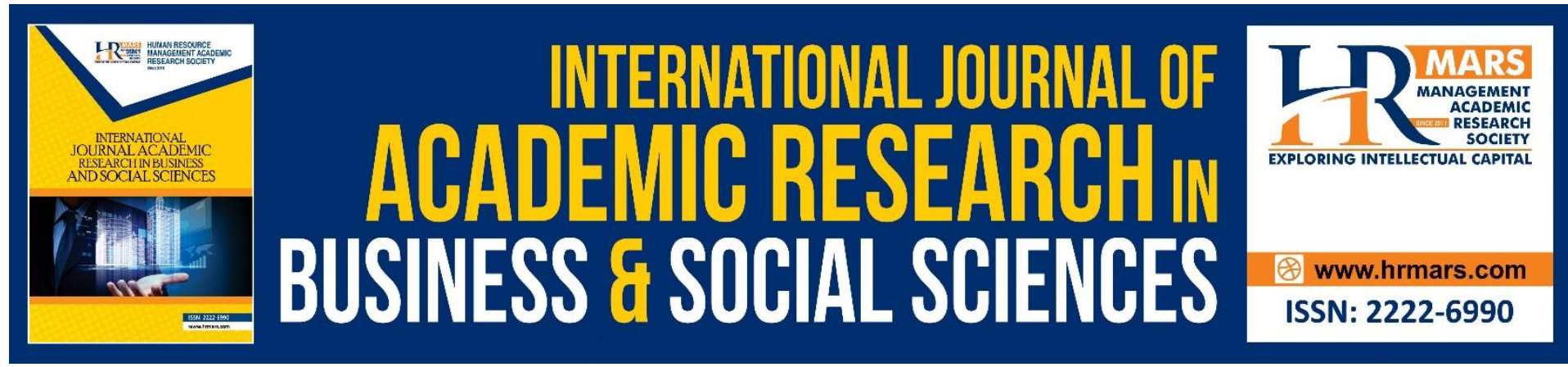

\title{
Integrated Marketing Strategies and Performance of Hospitality Firms Amidst the COVID-19 Pandemic
}

\author{
Glory Sunday Etim ${ }^{1}$, Edim Eka James ${ }^{2}$, Eyo Emmanuel \\ Essien $^{3}$, Victor Olusegun Okeowo ${ }^{4}$ \\ 1,2,3 Department of Marketing, University of Calabar, Nigeria, ${ }^{4}$ Department of Business \\ Management, University of Calabar, Nigeria \\ Corresponding Author Email: jamesedim@gmail.com
}

\begin{abstract}
Introduction: This study centered on integrated marketing strategies and performance of hospitality firms amidst the COVID-19 Pandemic. Our specific focus was to determine the effects of advertising, sales promotion, social media, and public relations on the performance of hotels as survival strategies amidst the COVID-19 pandemic.

Methodology: We adopted descriptive research design. Primary data were obtained from 226 customers of 15 hotels using a 5-point Likert scale questionnaire. Data analysis was done using descriptive statistics while hypotheses testing was carried out using multiple linear regression in the Statistical Package for the Social Sciences (SPSS 23).

Findings: The findings of the study revealed that advertising, sales promotion, social media and public relations had significant positive effects on performance of hotels.

Conclusions/and Recommendations: The findings of the study have provided reliable empirical evidence to confirm that the adoption of integrated marketing strategies such as advertising, sales promotion, social media and public relations could potentially enable hotels improve their marketing performance amidst the COVID-19 pandemic. Consequently, practical recommendations and suggestions for further research were made accordingly.

Keywords: Integrated Marketing Strategies, Hospitality Firms, Advertising; Sales Promotion, Social Media, Public Relations
\end{abstract}

\section{Introduction}

The Nigerian hospitality sector is one of the most affected industries by the COVID-19 pandemic; the industry's overall performance has been adversely affected by the travel restrictions and other restrictive constraints implemented by the Government against the pandemic (Odutola, 2021). Due to initial travel restrictions and the nationwide lockdown, the Nigerian tourism sector has witnessed a decline in tourist arrivals resulting in loss of hotels' revenue, which threatens to eliminate 149,400 hotel jobs thereby depriving the Nigerian economy of up to $\$ 1.1$ billion. Given that the Nigerian hospitality industry largely depends on foreign tourism, travel restrictions during the COVID-19 lockdown resulted in a 70 percent decline in hotel occupancy rates all through the most of February, 2020 (Odutola, 2021); a situation from which Nigerian hotels are still struggling to recover in the post-lockdown period. 
As part of a post-lockdown period recovery strategy, hospitality firms amidst the COVID-19 Pandemic have resorted to the use of integrated marketing strategies to rekindle consumer demand, and regain a competitive edge in the competitive hospitality industry (Amadi-Emina, 2021).

Integrated marketing is a strategy whereby companies deliver a unified, holistic message across all marketing channels at their disposal in order to achieve communication consistency and maximum communication impact on the target audience capable of ensuring the realization of organizational communication objectives (Šeric, Gil-Saura \& Ozretić-Došen, 2015). It is the integration, coordination and utilization of promotional mix elements and other marketing strategies by companies to disseminate coherent, consistent, harmonized and synchronized information to their target audiences to promote brand image, customer patronage, sales and marketing performance. Due to the imperatives of the integrated marketing approach, companies around the world are designing and implementing integrated marketing strategies in order to enhance their competitive standings in various industries, including tourism and hospitality (Nyambura, 2018; Ndizera, 2018). Hospitality firms amidst the COVID-19 Pandemic apply various integrated marketing strategies in their daily marketing operations; but the focus of this study centered on advertising, sales promotion, social media and public relations. From existing research, it has been established that hospitality firms, including hotels, apply the aforementioned and other integrated marketing strategies in their operations, to combat competition, encourage customer patronage, and enhance overall marketing performance (Obinwanne \& Ukabuilu, 2019; Šeric et al., 2015; Nyambura, 2018; Ndizera, 2018). In the context of Cross River State, it is common to see hotels advertise their services on television, radio, social media, billboards and posters. Hotels also offer sales promotional packages such as discounts, price-offs, premiums and bonus packs on a shortterm basis occasionally to attract customers. Public relations programmes such as event sponsorship, community involvement and media relations are also implemented by hotels in an effort to build positive corporate image.

Although not widely documented, the practice of marketing communication is not new to Nigerian hotels; it is a popular marketing strategy adopted by hotels in an effort to boost their performance (Ivuanyi, 2016). In the face of intense competition in the Nigerian hospitality industry, hotels apply various advertising strategies such as television, radio, outdoor, print and online advertising in the hopes of building brand awareness, and enhancing their competitive positions (Yusuf, 2019). Sales promotions of various types such as price discounts, bonus packs, and premiums are offered by hotels to customers as incentives to entice customer patronage. Similarly, motivated by digitization and cost-minimization, Nigerian hotels also use social media platforms to communicate with customers, delivery customer services and promote their offerings with the objective of influencing customer patronage (Okonkwo, Afamefuna \& Ololo, 2015). In the context of Cross River State, hospitality firms, such as hotels, also apply integrated marketing strategies such as advertising, sales promotion, social media and public relations in their operations; but the potential effect of these integrated marketing strategies on their performance is still widely undocumented. This is because there is insufficient empirical evidence from existing scholars to substantiate whether or not the integrated marketing strategies of hotels in Calabar have resulted in positive influences on their performance. 
Similarly, most studies on integrated marketing strategies and performance in Nigeria have focused on banks (Adesanoye, 2019); fast-moving consumer goods (Kehinde, 2009; Emeh, Anyaogu \& Kalu, 2018; Odiboh \& Ajayi, 2019; Iheaka, Njoku \& Ahaiwe, 2015); small and medium-sized enterprises (Muritala, 2021) and telecommunications companies (Oluwafemi \& Adebiyi, 2018; Egwuonwu, Adeniran \& Egwuonwu, 2017; Egwuenu \& Aliku, 2018). Only a few studies have addressed the subject in the context of hospitality firms in Nigeria (Obinwanne \& Ukabuilu, 2019). This entails that there is inadequate empirical backing for the relationship between integrated marketing strategies and hotel performance in Nigerian cities like Calabar, even though integrated marketing strategies are popularly implemented by hotels in Cross River State. There is therefore need for empirical studies to statistically demonstrate the extent to which the application of integrated marketing strategies has influenced the performance of hotels in Calabar, Cross River State. It is against this backdrop that the study was conducted to determine the effects of:

$>\quad$ advertising (outdoor advertising, television advertising, radio advertising) on the performance of hotels in Cross River State, Nigeria;

$>\quad$ sales promotion (price-off, discount, bonus pack) on the performance of hotels in Cross River State, Nigeria;

$>\quad$ social media (Facebook usage, Instagram usage, WhatsApp usage) on the performance of hotels in Cross River State, Nigeria; and

$>\quad$ public relations (event sponsorship, community engagement, customer relations) on the performance of hotels in Cross River State, Nigeria.

\section{Literature Review}

Theoretical Framework

The theoretical underpinning for this study is the resource-based view theory, propounded by Barney (1991). Propounded by Barney (1991), the resource-based view (RBV) is a managerial framework used to determine the strategic resources with the potential to deliver comparative advantage to a firm. Firms can harness their resources as a strategic way of gaining enduring competitive advantages. In that sense, the RBV model assumes that a firm's performance is derivative of its resource utilization. If a resource exhibits unique attributes, the resource enables the firm to gain and sustain competitive advantage. As such, the model encourages organizations to focus internally on their own resources with a view to harnessing them for better performance amidst competitive forces (Barney, 1991). Essentially, the focus of the RBV model is to redirect the attention of organizational management teams to the potential embedded in their internal resources, which could be managed and developed to improve organizational performance. Basically, the key assumption of the RBV model is that effective harnessing and utilization of organization's internal resources are central to enhancing their competitive performances. That is to say that the key to enjoying sustainable competitiveness lies within a company's internal resource stockpile or reservoir.

Proponents of the RBV model such as Ruivo, Oliveira and Neto (2015) argue that it is much more viable for organizations to take advantage of external opportunities by harnessing and deploying their current internal resources instead of attempting to obtain new capabilities from the external environment to harness emerging opportunities. In this model, there are two types of resources: tangible and intangible. Tangible assets are physical things and people. Land, buildings, machinery, equipment and capital - all these assets are tangible. While tangible resources could very well be imitated by competitors over the long haul, 
intangible resources, such as brand image, and brand loyalty are not possible to imitate by competitors, which is why the model posits that the purpose of tangible resources should be to sustainably develop intangible resources for companies that are impossible to imitate. Another primary idea propagated by the RBV model is that all resources are of varied degree of importance; some resources are more valuable and viable than others, and hence are more likely to improve a company's competitive position in the marketplace. This is because some resources (especially tangible resources) can very well be replicated or imitated by competitors, thereby undermining their impact on organizational competitive advantage as competitors can as well deploy such resources to rival the company. As such, the RBV model suggests that firms should use internal resources (both tangible and intangible) to identify, and develop core competencies in specific areas of business operations which would serve as a basis for implementing offensive and defensive strategies to ward off competitors, and boost organizational competitiveness.

The relevance of the resource-based view theory to the study is that integrated marketing strategies are key resources which could be exploited by hospitality firms, such as hotels, to achieve improved competitive advantages in terms of enhanced marketing performance. In that sense, the theory maintains that a firm's resources (including strategies) are the main source of improved performance, as such, the theory asserts that if hospitality firms look inward by exploiting resources at their disposal, including integrated marketing strategies, their performance will substantially be improved. The hypotheses of the study were therefore hinged on the basic premise of the resource-based view theory, which postulate that hospitality firms' performance can be improved if they exploit internal resources at their disposal (in this case, integrated marketing strategies). The veracity of the theoretical postulation was subsequently confirmed in the study, which confirmed a significant effect of integrated marketing strategies on the performance of hotels in Nigeria.

\section{Conceptual Framework}

The study examined integrated marketing strategies and the performance of hospitality firms amidst the COVID-19 Pandemic. Its specific aim was to determine the effect of the independent variable (integrated marketing strategies) on the dependent variable (hotel performance). To that end, the independent variable (integrated marketing strategies) were decomposed into specific indicators namely: advertising, sales promotion, social media and public relations; whereas, the indicators of the dependent variable (hotel performance) included: brand recognition, customer patronage, customer retention, and sales volume. In the context of this study, advertising is defined as the non-personal promotion of hospitality services through the mass media by firms to improve their performance. Sales promotion is the short-term incentives offered to customers by hospitality firms to encourage patronage and repeat patronage. Social media is a collection of interactive internet-based platforms like Facebook, used by hospitality firms to communicate with customers and promote their services. Whereas, public relations include programmes such as event sponsorships, customer and media relations implemented by hospitality firms to enhance corporate image and acquire public goodwill. Informed by existing empirical studies, this research hypothesized that through these specific indicators, integrated marketing strategies have some form of associations with the performance of hotels. Consequently, a conceptual model has been developed to visually portray the relationship between integrated marketing strategies and hotel performance as hypothesized in the study. 


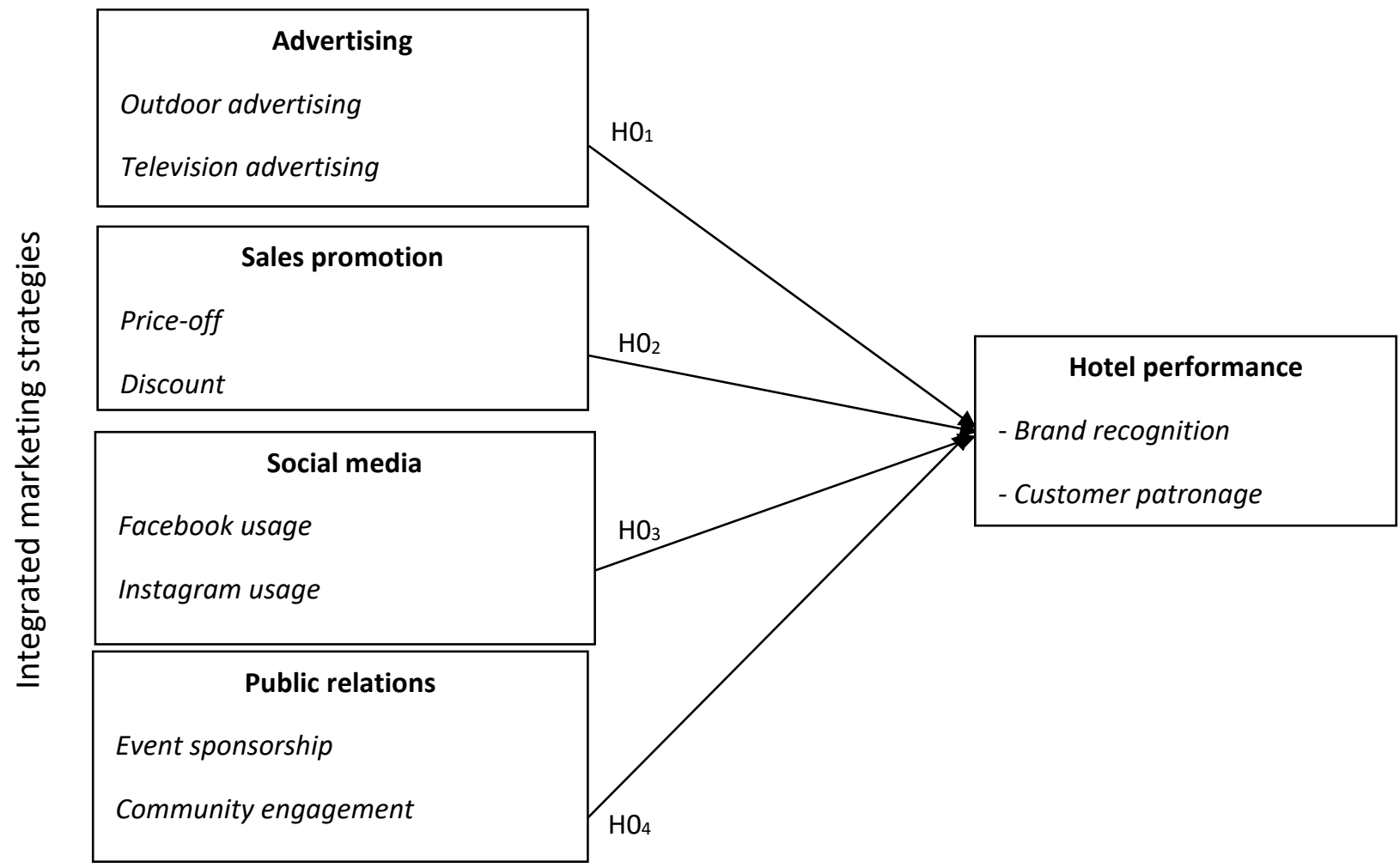

FIG. 1: Conceptual model of the study

Source: Adapted from Al-Qeedaa (2019); Obinwanne and Ukabuilu (2019)

\section{Integrated Marketing Strategy}

Integrated marketing a strategy whereby companies deliver a unified, holistic message across all marketing channels at their disposal in order to achieve communication consistency and maximum communication impact on the target audience capable of ensuring the realization of organizational communication objectives (Šeric, Gil-Saura \& Ozretić-Došen, 2015). It is the integration, coordination and utilization of promotional mix elements and other marketing strategies by companies to disseminate coherent, consistent, harmonized and synchronized information to their target audiences to promote brand image, customer patronage, sales and marketing performance. According to Al-Qeedaa (2019), integrated marketing is an approach to marketing communication that harnesses the individual potential of all promotional tool in a firm's promotional mix in concert with any other marketing strategy to maximize the chances of realizing the promotional objectives of the firm. Instead of developing separate messages, contents and appeals for each promotional tool as would be obtained in the traditional form of communication; an integrated marketing strategy develops a unified, consolidated and coherent promotional campaign that is executed across all the promotional channels at a firm's disposal simultaneously such that the target audience obtains a unified message without equivocation or ambiguity. This builds customers' trust, prevents customers' confusion and unequivocally delivers a firm's messages to the target audience thereby maximizing the probability of eliciting desired responses from consumers.

\section{Performance of Hospitality Firms}

The performance of hospitality firms is the effectiveness and efficiency of the operations of hospitality firms over a specific period of time (Reyes-Santiago, Sánchez-Medina \& DíazPichardo, 2019). It is how cost-efficient and revenue-effective the activities of a hospitality firm have been in comparison with its performance objectives and goals. It measures the 
degree to which a hospitality firm's established corporate objectives and goals are achieved by its marketing, and managerial strategies over a period of time (Zawadi \& Makena, 2019). The indicators of performance in the hospitality industry include the following: brand recognition, guest occupancy rates, customer patronage, customer satisfaction, customer preference, customer retention, brand advocacy, corporate image, sales volume, market share, sales revenue, new product success rates, and profitability ( $Q u, 2014$; Bruni et al., 2017; Al-Azzam, 2016). According to Abdul, Munyoki and Burugu (2016), while assessing performance, hospitality firms evaluate the contributions of their business strategies to performance in order to determine the most significant contributing strategies and the least contributing strategies so that remedial actions can be taken. In the event where certain business or managerial strategies are found to be positively and significantly contributing to performance, such strategies are intensified and reinforced so as to enhance performance. Alternatively, if the strategies are not contributing significantly, a strategic hospitality business manager should withdraw them from the strategic mix in order to prevent them from subverting performance over the long haul.

In the view of Zawadi and Makena (2019), periodic evaluation of performance is fundamental to a hospitality firm's ability to achieve competitive advantage in the following ways: periodic performance assessment enables hospitality firms to know how their resources are being spent and whether or not they yield meaningful returns on investment; it enables hospitality firms to carefully allocate their resources to strategies, campaigns and programmes that are contributing significantly to performance; it exposes the weaknesses or ineffectiveness of some business/marketing strategies, campaigns and programmes, thereby enabling managers to take corrective measures; it provides information on the business initiatives and strategies of a hospitality firm over the past years with a view to developing a new set of strategies to effectively achieve corporate objectives in the future, etc Other reasons why hospitality firms evaluate their performance include: monitoring business progress towards annual goals; determining what areas of the marketing mix - product, price, place, and promotion - need modification or improvement to increase some aspect of performance; and assessing whether hospitality offerings (products, services, attractions, etc) meet customers' and stakeholders' needs (Gretchen, 2016).

\section{Advertising and Performance of Hospitality Firms}

Advertising is the process of communicating a message about goods and services to a customer (Ul-Abideeen \& Saleem, 2013). Advertisements could be delivered via a wide variety of media, including but not limited to conventional channels like billboards, magazines, newspapers, radio, television, direct mail; as well as emerging media such as electronic mail, social media, application software, and the internet. Advertising is one of the most critical components of marketing. It includes promotional campaigns that use audio, video, text or a combination of the aforementioned to deliver intended messages and content to an identified target audience in a non-personal context. Even though advertising is mostly used by business organizations to sell their offerings, non-governmental organizations, institutions and entities are increasingly using advertising channels to communicate their message and content to intended target audiences. Riley (2016) observes that advertising is any paid form of communication from an identified sponsor or source that draws attention to ideas, goods, services or the sponsor itself. It is directed toward groups rather than individuals, and it is usually delivered through media such as television, radio, newspapers and, increasingly, the 
Internet. As a popular promotional strategy, advertising has been confirmed to possess the capacity to improve brand awareness, customer patronage, sales volume and overall performance of business organizations (Gbandi \& Kadiri, 2015). The scholarly assertion is supported by the study of Bezabih (2021), which revealed that advertising had a significant positive effect on the performance of hotels in Addis Ababa. Similarly, the assertion corresponds with the study of Aransyah, Althalets, Wediawati and Sari (2020), which revealed that advertising had a significant effect on room occupancy rates in Mesra Business and Resort Hotel, Samarinda, Indonesia.

\section{Sales Promotion and Performance of Hospitality Firms}

Sales promotion as a collection of short-term incentive or inducement tools designed and implemented with the objective of enticing and stimulating increased or immediate purchase or usage of products or services by consumers or marketing intermediaries (distributors, dealers, wholesalers, and retailers) (Carlos \& Maricruz, 2016). In the views of Wang, Xi and Liam (2011), sales promotion is a direct incentive offered to a sales force, distributor, or consumer, with the primary objective of creating an immediate sale. They further assert that sales promotion refers to those time-bound or limited promotional activities other than advertising, publicity and personal selling that stimulate interest, trial or purchase by final customers or other intermediaries in the channel. They include short-term marketing efforts that are supplementary in nature and are intended to induce immediate sales. According to Esu (2012), sales promotion is a short-term inducement or incentive directed at consumers or traders (middlemen) to stimulate consumer purchase and dealer effectiveness. It is essentially a promotional tool used by business organizations to attract market attention and stimulate customer patronage of products or services for a short duration, especially during downturns or off-peak seasons. Over the years, sales promotion has proven to be an efficacious and efficient promotional tool for substantially and rapidly enhancing sales and overall marketing performance over the short-term. Various sales promotional methods such as discounts, premium, samples, bundles, bonus packs and coupons have been applied by business organizations around the world to substantially increase customer patronage and sales performance (Abimbola, Abioro \& Okeowo (2020). The foregoing viewpoint is reinforced by the study of Obinwanne and Ukabuilu (2019), which revealed that sales promotion had a significant positive effect on brand equity and sales performance of hotels in Uyo. The viewpoint is also substantiated by the study of Bezabih (2021), which revealed that sales promotion had a significant positive effect on the performance of hotels in Addis Ababa.

\section{Social Media and Performance of Hospitality Firms}

Social media is a collection of online communications channels dedicated to communitybased input, interaction, content-sharing and collaboration (Strauss \& Frost, 2011). It includes interactive computer-mediated technologies that facilitate the creation and sharing of information, ideas, career interests and other forms of expression via virtual communities and networks. Social media is an electronic system that enables the creation, storage and dissemination of information, and contents between and among online-based communities (Carr \& Hayes, 2015). It allows registered participants to generate, design, edit, share and disseminate contents such as audio, video, texts, documents, pictures and links to users across the globe without geographical constraints. It is a tool used to describe the type of media that is based on conversations and interactions between and among people online (Fuchs, 2021). According to Nisrina (2019), the emergence of social media tools (such as 
Facebook, Twitter, Instagram and YouTube) has created platforms for individuals and organizations to create or shape certain behavioural tendencies in their audiences by enabling the rapid, far-reaching, and widespread dissemination of messages and other contents from the comfort of their homes or business places. As a core element of the direct marketing strategy, social media has been found to possess the capacity to significantly and positively improve the marketing performance of companies around the world. This premise is well supported by the study of Al-Qeedaa (2019), which revealed that social media marketing was positively correlated, and significantly impacted hotels' marketing performance. Similarly, the premise is backed by the study of Muriuki (2015), which revealed that social media had a significant positive influence on the performance of insurance companies in Nairobi.

\section{Public Relations and Performance of Hospitality Firms}

Public relations is the management of the interactions or relationships and communications between a business and its publics (Esu, 2012). Stanley (2007) defines public relations as a management function that determines the attitudes and opinions of the organization's publics, identifies its publics, and formulates and executes a programme of action to promote mutual understanding and cooperation between organizations and their stakeholders. In the view of Stobber (2011), public relations is the management of the communications and relationships to establish goodwill and mutual understanding between an organization and its publics. Ebitu (2012) perceives public relations as a systematic effort by an organization to identify, create, promote and sustain a favourable relationship, understanding and goodwill capable of portraying the organization in a good light with its publics. Public relations strategies (such as community development, corporate philanthropy, media relations, customer relations, sponsorships, events, and etcetera) have been used by companies to create and maintain a positive corporate image and to obtain the good will of the public, all of which facilitates the acceptance of their offerings by the target audience, hence effectively accelerating their marketing performance (Abu-Jamul, Mustapha \& Hussein, 2018). This proposition is backed by the study of Tsion (2021), which revealed that public relations had a positive and significant effect on consumer preference for five-star franchised hotels in Addis Ababa. The proposition is also reinforced by the study of Muriuki (2015), which revealed that public relations had a significant positive influence on the performance of insurance companies in Nairobi.

\section{Empirical Review}

Obinwanne and Ukabuilu (2019) conducted a study on "Utilization of integrated marketing communication tools for brand recognition and sales in hotels". The study obtained primary data from 80 senior staff of 5 randomly selected hotels in Uyo, Akwa Ibom State, Nigeria using a structured questionnaire. Multiple Regression was used to analyze the data using the Ordinary Least Squares (OLS) method. The findings of the study revealed that sales promotion and personal selling had significant positive effects on brand equity and sales performance of hotels in Uyo, whereas, the effects of advertising and direct marketing in this regard were non-significant. Therefore, the study concluded that integrated marketing communication largely affect the performance of hotels positively and significantly. Al-Qeedaa (2019) examined the "Impact of integrated marketing communications (IMCs) on hotels' marketing performance". The study obtained primary data from 300 managers and guests of 5-star hotels in Abu-Dhabi city, United Arab Emirates. Multiple linear regression was adopted to test the study hypotheses statistically. The findings of the study revealed that public relations, 
advertising, and social media marketing as integrated marketing tools are positively correlated, and significantly impact hotels' marketing performance. Hence, the study concluded that integrated marketing communication significantly influences the marketing performance of hotels in the United Arab Emirates.

Bezabih (2021) examined "The effects of integrating marketing communication on performance of hotel in Ethiopia: The case of selected hotels in Addis Ababa". The researcher obtained primary data from 105 employees of selected hotels in Addis Ababa using a structured questionnaire. Data analysis was carried out using descriptive statistics (frequency tables and mean), Pearson's correlation and multiple regression. The findings revealed that advertising, sales promotion, direct marketing and personal selling had significant positive effects on the performance of hotels in Addis Ababa. Therefore, the study concluded that integrated marketing communication has a significant positive effect on hotel performance in the Ethiopian hospitality industry. Tsion (2021) conducted a study on "The effect of promotional mix practices on customer preference the case of five-star franchised hotels in Addis Ababa". The study obtained primary data from 385 customers of five-star franchised hotels in Addis Ababa through a 5-point Likert Scale questionnaire. Data analysis was carried out using descriptive statistics (mean, and simple percentage), correlation and multiple regression analysis. The findings of the study revealed that advertising, sales promotion, direct marketing, personal selling and public relations had positive and significant effects on consumer preference for five-star franchised hotels in Addis Ababa. Hence, the study reached the conclusion that promotional mix practices have significant positive effects on consumer preference for five-star hotels in Addis Ababa.

Muriuki (2015) conducted a study on "The influence of marketing communication practices on the performance of insurance companies in Kenya". The study obtained primary data from 48 registered insurance companies in Nairobi using a structured questionnaire. The obtained data were analyzed using descriptive statistics and regression analysis. The findings of the study revealed that advertising, social media, public relations, personal selling and sales promotion had significant positive influences on the performance of insurance companies in Nairobi. Hence, the study concluded that marketing communication practices have a significant positive influence on the performance of insurance companies in Kenya. Oluwafemi and Adebiyi (2018) conducted a study on "Customer loyalty and integrated marketing communications among subscribers of telecommunication firms in Lagos Metropolis, Nigeria". The study obtained primary data from 134 subscribers of telecommunication networks in Lagos Metropolis using a 5-point Likert scale questionnaire. The data were analyzed using descriptive and inferential statistics (correlation and regression), while hypotheses were tested using the analysis of variance (ANOVA). The findings of the study revealed that direct marketing, publicity, sales promotion and advertising had significant relationships with customer loyalty towards telecommunication firms in Lagos. Therefore, the study concluded that integrated marketing communication had a significant relationship with customer loyalty in the Nigerian telecommunications industry.

Khan (2016) conducted a study on the "Impact of promotional mix elements on tourist's satisfaction: A case study of Mussoorie". The study collected primary data from 200 respondents in India using a survey questionnaire. The data were statistically analyzed using descriptive statistics and simple linear regression. The findings of the study revealed that 
advertising, sales promotion and public relations had significant impacts on tourists' satisfaction, while direct marketing had a non-significant impact on tourists' satisfaction in Mussoorie Resort. Hence, the study concluded that promotional mix had a significant impact on tourists' satisfaction in the Indian hospitality industry. Finally, Aransyah, Althalets, Wediawati and Sari (2020) conducted a study on "The impact of promotion on room occupancy rate in Mesra Business and Resort Hotel, Samarinda, Indonesia". The study obtained primary data from 70 respondents in Samarinda, Indonesia using interviews and questionnaire. The data obtained were analyzed using simple linear regression method with the help of the Statistical Package for the Social Sciences (SPSS) software. The findings of the study revealed that advertising, direct sales, sales promotion, publicity, and word of the mouth simultaneously had significant effects on room occupancy rates in Mesra Business and Resort Hotel, Samarinda, Indonesia. Therefore, the study concluded that promotional mix has a positive and significant effect on room occupancy rates as well as consumers' decisions to choose a place to stay at the Mesra Business and Resort Hotel, Indonesia.

\section{Research Methodology}

For this study, descriptive research design was adopted. The study used a judgmental sampling technique to include 226 customers of hotels in Calabar Metropolis into the sampling frame. Primary data were obtained from hotel customers with the aid of a 5-point Likert scale questionnaire. The instrument comprised two distinct sections, namely: Section A (which elicited respondents' demographic information such as age, gender and marital status) and Section B (which contained statements drawn from the study variables: advertising, sales promotion, social media, public relations and performance of hotels. Statements 1 - 3 measured advertising (outdoor advertising, television advertising, and radio advertising); statements 4-6 measured sales promotion (price-off, discount and bonus pack); statements 7 - 9 measured social media (Facebook usage, Instagram usage and WhatsApp usage); statements $10-12$ measured public relations (event sponsorship, community engagement and customer relations); whereas, statements $13-16$ measured hotel performance (brand recognition, customer patronage, customer retention, and sales volume). The Likert scales adopted were as follows: Strongly Agree ( $S A=5$ points); Agree (A = 4 points); Undecided ( $U=3$ points); Disagree ( $D=2$ points); and Strongly Disagree (SD = 1 point). Content validity was adopted to validate the instrument, while it was checked for internal consistency and confirmed using Cronbach's alpha coefficients. Consequently, all measurement scales on the questionnaire generated Cronbach's alpha coefficients of 0.7 and above, hence indicating that the instrument was reliable. Subsequently, the data obtained in the study were analyzed using descriptive statistics, whereas the study hypotheses were tested using multiple linear regression with the aid of IBM SPSS 23. 
Table 1: Reliability coefficients

\begin{tabular}{|l|l|l|}
\hline Variables & Number of items & Cronbach's alpha \\
\hline Advertising & 3 & .880 \\
\hline Sales promotion & 3 & .739 \\
\hline Social media & 3 & .767 \\
\hline Public relations & 3 & .832 \\
\hline Performance of hotels & 4 & .771 \\
\hline & $\mathbf{1 6}$ & \\
\hline
\end{tabular}

Source: Field survey (2021)

\section{Data Analysis and Findings}

Table 2: Model summary of the effect of integrated marketing strategies on performance of hotels

\begin{tabular}{|l|l|l|l|l|}
\hline Model & $R$ & $R$ Square & Adjusted R Square & $\begin{array}{l}\text { Std. Error of the } \\
\text { Estimate }\end{array}$ \\
\hline 1 & $.880^{\mathrm{a}}$ & .774 & .769 & .19324 \\
\hline
\end{tabular}

a. Predictors: (Constant), Advertising, sales promotion, social media and public relations

Table 3: ANOVA ${ }^{a}$ of the effect of integrated marketing strategies on performance Of hotels

\begin{tabular}{|l|l|l|l|l|l|}
\hline \multicolumn{2}{|l|}{$\begin{array}{l}\text { Model } \\
\text { Sum of } \\
\text { Squares }\end{array}$} & Df & $\begin{array}{l}\text { Mean } \\
\text { Square }\end{array}$ & F & Sig. \\
\hline $\begin{array}{lllll}\text { Regression } \\
\text { Residual }\end{array}$ & 28.189 & 4 & 7.047 & 188.715 & $.000^{\mathrm{b}}$ \\
Total & 8.253 & 221 & .037 & & \\
\hline
\end{tabular}

a. Dependent Variable: Performance of hotels

b. Predictors: (Constant), Advertising, sales promotion, social media and public relations

Table 4: Coefficients ${ }^{\mathrm{a}}$ of the effect of integrated marketing strategies on performance of hotels

\begin{tabular}{|c|c|c|c|c|c|}
\hline \multirow[b]{2}{*}{ Model } & \multicolumn{2}{|c|}{$\begin{array}{l}\text { Unstandardized } \\
\text { Coefficients }\end{array}$} & \multirow{2}{*}{\begin{tabular}{|l} 
Standardized \\
Coefficients \\
Beta \\
\end{tabular}} & \multirow[b]{2}{*}{$T$} & \multirow[b]{2}{*}{ Sig. } \\
\hline & $B$ & Std. Error & & & \\
\hline $1 \quad$ (Constant) & 1.302 & .090 & & 14.476 & .000 \\
\hline Advertising & .125 & .028 & .181 & 4.426 & .000 \\
\hline Sales promotion & .154 & .036 & .403 & 4.341 & .000 \\
\hline Social media & .116 & .046 & .247 & 2.522 & .012 \\
\hline Public relations & .198 & .020 & .379 & 9.799 & .000 \\
\hline
\end{tabular}

a. Dependent Variable: Performance of hotels 
Interpretation of Result

The results on the Tables 2, 3 and 4 are multiple linear regression results of the effect of integrated marketing strategies on performance of hotels. The correlation coefficient $(R)$ of 88.0 percent on Table 2 indicates that the relationship between integrated marketing strategies and performance of hotels is 88.0 percent, signifying a very high degree of relationship between the variables. The coefficient of determination (R2) of 0.774 on Table 2 implies that up to 77.4 percent of the variability in the performance of hotels can be explained by integrated marketing strategies. The F-test $(188.715, \mathrm{P}<0.05)$ statistic on Table 3 indicate that the regression model is statistically significant i.e., integrated marketing strategies significantly predict the performance of hotels. Furthermore, Table 4 shows that the $p$-values of all independent variables tested are below the error margin of 0.05 [advertising ( $p$-value $=$ $0.000)$, sales promotion ( $p$-value $=0.000)]$, social media $(p$-value $=0.012)$, and public relations $(p$-value $=0.000)]$. Therefore, the study rejected all null hypotheses, accepted all alternative hypotheses and concluded that advertising, sales promotion, social media and public relations had significant positive effects on performance of hotels in Calabar, Cross River State.

and above.

\section{Discussion of Findings}

The test of hypothesis one revealed that advertising has a significant positive effect on performance of hotels. This finding is backed by the study of Bezabih (2021), which revealed that advertising had a significant positive effect on the performance of hotels in Addis Ababa. Similarly, the finding is substantiated by the study of Aransyah, Althalets, Wediawati and Sari (2020), which revealed that advertising had a significant effect on room occupancy rates in Mesra Business and Resort Hotel, Samarinda, Indonesia. This implies that as a popular integrated marketing strategy, advertising has been confirmed through substantive empirical evidence to significantly enhance the performance of hotels.

From the test of hypothesis two, it was revealed that sales promotion has a significant positive effect on performance of hotels. This finding is supported by the study of Obinwanne and Ukabuilu (2019), which revealed that sales promotion had a significant positive effect on brand equity and sales performance of hotels in Uyo. The finding is also substantiated by the study of Bezabih (2021), which revealed that sales promotion had a significant positive effect on the performance of hotels in Addis Ababa. The implication of this finding is that sales promotion has been confirmed through substantive empirical evidence to significantly enhance the performance of hotels.

Furthermore, the test of hypothesis three revealed that social media has a significant positive effect on performance of hotels. This finding is reinforced by the study of Al-Qeedaa (2019), which revealed that social media marketing was positively correlated, and significantly impacted hotels' marketing performance. Similarly, the study is backed by the study of Muriuki (2015), which revealed that social media had a significant positive influence on the performance of insurance companies in Nairobi. This finding implies that the study has generated substantive empirical evidence that confirms the capacity of social media to significantly enhance the performance of hotels. 
Finally, the test of hypothesis four revealed that public relations has a significant positive effect on performance of hotels. This finding is substantiated by the study of Tsion (2021), which revealed that public relations had a positive and significant effect on consumer preference for five-star franchised hotels in Addis Ababa. The finding is also reinforced by the study of Muriuki (2015), which revealed that public relations had a significant positive influence on the performance of insurance companies in Nairobi. The implication of this finding is that empirical evidence has been able to confirm that, as an integrated marketing strategy, public relations significantly enhances the performance of hotels.

\section{Conclusion}

In the past several years, empirical studies have been conducted by scholars around the world across industries to statistically generate empirical evidence that demonstrates the effect of integrated marketing strategies on the performance of business organizations. To that effect, researchers in the hospitality industry have sought to determine the causal relationship between various integrated marketing strategies and the performance of hospitality firms around the world (Khan, 2016; Obinwanne \& Ukabuilu, 2019; Al-Qeedaa, 2019; Bezabih, 2021; Tsion, 2021; Aransyah, Althalets, Wediawati \& Sari, 2020). Like previous studies, this research examined integrated marketing strategies and the performance of hospitality firms. It was geared towards empirically demonstrating how the implementation of integrated marketing strategies (advertising, sales promotion, social media and public relations) has affected the performance of hotels in response to the challenges imposed by the new normal inspired by the Covid-19 pandemic in Nigeria. Primary data were obtained from customers of hotels using a structured questionnaire; whereas data analysis was carried out using descriptive and inferential statistics. The findings of the study revealed that advertising, sales promotion, social media and public relations had significant positive effects on performance of hotels. The implication of these findings is that hospitality firms including hotels could substantially enhance their performance by designing and implementing integrated marketing strategies such as advertising, sales promotion, social media and public relations. Therefore, the study concludes that in the new normal brought on by the COVID-19 pandemic, hospitality firms can sustainably bolster their performance through the implementation of integrated marketing strategies.

\section{Practical Implications}

Amidst the global COVID-19 pandemic, hospitality firms, like all business organizations, are concerned about reinforcing their strategic positions to prevent the adverse impacts of the pandemic on their commercial operations. Through the findings of this study, we have been able to provide substantive empirical evidence to confirm that the adoption of integrated marketing strategies such as advertising, sales promotion, social media and public relations could potentially enable hospitality firms, including hotels, to improve their marketing performance as a way of reinforcing their strategic marketing positions amidst the COVID-19 pandemic. To achieve this, some practical marketing steps must be taken and decisions executed effectively and efficiently. Firstly, hospitality firms should use effective advertising media such as billboards, posters, television and radio commercials to advertise products and services in order to create awareness, persuade customers and encourage customer patronage. Secondly, sales promotions such as price reductions, discounts and bonus packs should be offered to customers as incentives for encouraging customer patronage and repeat patronage behaviour towards hospitality firms. Thirdly, considering its effectiveness, cost- 
efficiency and wide coverage, social media should increasingly be utilized alongside other communication media by hospitality firms to promote their offerings and improve customer patronage and retention. And finally, hospitality firms should implement public relations programmes such as event sponsorships, community engagement and customer relations in order to improve their corporate image and maintain cordial relations with stakeholders, who are central to improving sales and marketing performance in the long run.

\section{Limitations and suggestions for further research}

The focus of this study was constrained to four (4) integrated marketing strategies, namely: advertising, sales promotion, social media and public relations; therefore, there is need for more comprehensive studies that take into account the potential influence of other integrated marketing strategies such as direct marketing, publicity, personal selling and wordof-mouth communication on hotels' performance. Such studies will definitely widen the scope of discourse on the subject of this research and improve the generalizability of its findings. Also, this study was overwhelmingly geared towards hotel customers; hence it is incapable of providing explanation as to how integrated marketing strategies have enabled managers and employees of hospitality firms to create and deliver required hospitality services to customers. There is therefore need for studies that include managers and servicedelivery employees of hotels in their sampling frames in order to provide empirical explanation of the influence of integrated marketing strategies on their service promotion and delivery processes. Finally, intending researchers should extend the scope of their studies beyond hotels, to include other hospitality enterprises such as restaurants, travel and tour, recreation, and destination marketing firms in order to provide a more holistic view of the influence of integrated marketing strategies on the performance of hospitality firms amidst the COVID-19 pandemic.

\section{References}

Abdul, U., Munyoki, M., \& Burugu, A. (2016). The impact of social media marketing on the marketing performance of small and medium enterprises in Nairobi, Kenya. International Journal of Management Reviews, 32(16), 141-152

Abimbola, O., Abioro, M., \& Okeowo, E. (2020). Promotional mix and customer patronage: A study of telecom subscribers in Lagos and Ogun States, Nigeria. Covenant Journal of Business \& Social Sciences, 11, 80-106.

Abu-Jamul, R., Mustapha, H., \& Hussein, J. (2018). Effect of marketing communications on the performance of hotel organizations in Beirut. Global Journal of Hospitality and Travel Management, 18(6), 19-31

Adesanoye, O. (2019). Integrated marketing communication tools and customers' perception and attitudes to the brands of selected Nigerian banks. Acta Universitatis Danubius. Communicatio, 13(2), 26-40.

Al-Azzam, A. F. (2016). The impact of customer relationship management on hotels performance in Jordan. International Journal of Business and Social Science, 7(4), 200210.

Al-Qeedaa, M. A. (2019). Impact of integrated marketing communications (IMCs) on hotels' marketing performance. International Journal of Innovation, Creativity and Change, 8(9), 304-323

Amadi-Emina, A. (2021). Post-lockdown: How Nigerian hotels are staging a comeback. What the road to recovery looks like for hotels in Nigeria. Retrieved from: 
https://www.stearsng.com/premium/article/post-lockdown-how-nigerian-hotels-arestaging-a-comeback

Aransyah, M. F., Althalets, F., Wediawati, T. \& Sari, A. I. (2020). The impact of promotion on room occupancy rate in Mesra Business and Resort Hotel, Samarinda, Indonesia. International Journal of Applied Sciences in Tourism and Events, 4(2), 150-157

Barney, J. B. (1991). Firm resources and sustained competitive advantage. Journal of Management, 17(1), 99-120.

Bezabih, Y. (2021). The effects of integrating marketing communication on performance of hotel in Ethiopia: The case of selected hotels in Addis Ababa [Master Dissertation, St. Mary's University, South Sudan]

Bruni, A., Cassia, F., \& Magno, F. (2017). Marketing performance measurement in hotels, travel agencies and tour operators: A study of current practices. Current Issues in Tourism, 20(4), 339-345.

Carlos, U., \& Maricruz, B. (2016). Sales promotion and customer patronage of computers and accessories in Havana. Journal of Emerging Trends in Marketing, 4(3), 221-239

Carr, C. T., \& Hayes, R. A. (2015). Social media: Defining, developing, and divining. Atlantic Journal of Communication, 23(1), 46-65.

Ebitu, E. T. (2012). Marketing communications: An integrated approach (1 ${ }^{\text {st }} \mathrm{Ed}$.). Calabar: University of Calabar Printing Press

Egwuenu, A. S., \& Aliku, I. H. (2018). Integrated marketing communication program and brand performance in the Nigerian telecommunications industry. Journal of Business and Management, 20(5), 70-89

Egwuonwu, T. K., Adeniran, J. A., \& Egwuonwu, C. O. (2017). Integrated marketing communications and customer loyalty in Nigeria's telecommunications industry. International Business and Management, 14(2), 18-28.

Emeh, P. C., Anyaogu, P. M., \& Kalu, I. N. (2018). Effect of integrated marketing communication (IMC) on firms' sales volume: A study of Nigeria's food and beverage industry. International Journal of Integrated Marketing Communications, 3(1), 60-81

Esu, B. B. (2012). Introduction to marketing (2 ${ }^{\text {nd }}$ Ed.). Calabar: Jochrisam Publishers.

Familmaleki, M., Aghighi, A., \& Hamidi, K. (2015). Analyzing the influence of sales promotion on customer purchasing behavior. International Journal of Economics \& Management Sciences, 4(4), 1-6.

Fuchs, C. (2021). Social media: A critical introduction. Thousand Oaks: Sage Publications

Gbandi, E. C., \& Kadiri, P. A. (2015). Advertising and customers patronage of commercial road transport services in Benin City. Nigeria Journal of Business Administration, 13(1), 78104

Gretchen, W. (2016). Evaluating marketing performance. Retrieved from: https://courses.lumenlearning.com/boundless-marketing/chapter/evaluatingmarketing-performance/

Iheaka, E. E., Njoku, M. S. \& Ahaiwe, E. O. (2015). Effect of integrated marketing communications in driving new product diffusion and adoption: A case of Hypo Bleach in Aba Metropolis of Abia State, Nigeria. European Journal of Business and Social Sciences, 4(05), 157-164.

Ivuanyi, O. C. (2016). Promotional problems in hospitality industry (A study of selected hotels in Enugu Urban) (Doctoral dissertation, University of Nigeria, Enugu).

Kehinde, O. J. (2009). Integrated Marketing Communications and consumers patronage of Nigerian beverage products [Doctoral dissertation, Covenant University, Ota.]. 
Khan, M. S. (2016). Impact of promotional mix elements on tourist's satisfaction: A case study of Mussoorie. International Journal of Research in Commerce \& Management, 7(4), 98101

Muritala, I. (2021). Integrated marketing communication and brand equity of small enterprises in Kwara State [Doctoral dissertation, Kwara State University, Nigeria].

Muriuki, I. M. (2015). The influence of marketing communication practices on the performance of insurance companies in Kenya [M.Sc. thesis, University of Nairobi].

Ndizera, V. (2018). Integrated marketing communication for tourism and hospitality: A case of selected star and non-star category Rwandan hotels. Hospitality Frontiers, 5(1), 3651

Nisrina, S. (2019). Impact of public relations strategies on organizational performance in Bali's tourism industry. Journal of Public Relations Research, 4(6), 208-219

Nyambura, M. R. (2018). Influence of integrated marketing communication on performance of hotels in the hospitality industry: A study of small catering firms in Kenya. Journal of Tourism and Hospitality Marketing, 17(9), 104-118

Obinwanne, C. O., \& Ukabuilu, E. N. (2019). Utilization of integrated marketing communication tools for brand recognition and sales in hotels. Journal of Hotel Management and Tourism Research, 4(1), 29-38

Odiboh, O., \& Ajayi, F. (2019). Integrated marketing communication and carbonated drinks consumers in Nigeria: A consumerist analysis. Proceedings of the 33rd International Business Information Management Association (IBIMA), 10-11.

Odutola, A. (2021). Nigeria's hospitality sectors face investment shortages as spate of abandoned projects increase. Retrieved from:

https://nairametrics.com/2021/03/12/nigerias-hospitality-sectors-face-investmentshortages-as-spate-of-abandoned-projects-increase/

Okonkwo, E. E., Afamefuna, E., \& Ololo, N. G. (2015). Social media platforms and their contributions to tourism development and promotion in Nigeria. Nsukka Journal of the Humanities, 23(2), 103-117.

Oluwafemi, A. J. \& Adebiyi, S. O. (2018). Customer loyalty and integrated marketing communications among subscribers of telecommunication firms in Lagos Metropolis, Nigeria. Journal of Competitiveness, 10(3), 101-118.

Qu, R. (2014). Market orientation and organizational performance linkage in Chinese hotels: The mediating roles of corporate social responsibility and customer satisfaction. Asia Pacific Journal of Tourism Research, 19(12), 1399-1416.

Reyes-Santiago, M., Sánchez-Medina, P. S., \& Díaz-Pichardo, R. (2019). The influence of environmental dynamic capabilities on organizational and environmental performance of hotels: Evidence from Mexico. Journal of Cleaner Production, 227, 414-423.

Riley, C. (2016). Advertising: Pay to play. Retrieved from: https://courses.lumenlearning.com/marketing-spring2016/chapter/readingadvertising/

Rosenbaum-Elliott, R. (2021). Strategic advertising management. Oxford: Oxford University Press.

Ruivo, P., Oliveira, T., \& Neto, M. (2015). Using resource-based view theory to assess the value of ERP commercial-packages in SMEs. Computers in Industry, 73, 105-116.

Saravanakumar, M., \& Sugantha, T. (2012). Social media marketing. Life Science Journal, 9(4), 4444-4451. 
Šeric, M., Gil-Saura, I., \& Ozretić-Došen, Đ. (2015). Insights on integrated marketing communications: Implementation and impact in hotel companies. International Journal of Contemporary Hospitality Management, 8(2), 78-89

Stanley, O. (2007). Marketing communication: An integrated approach (2 $\left.{ }^{\text {nd }} E d.\right)$. Enugu: Daylight Printing Press.

Stobber, B. (2011). Public relations: A total corporate distraction. Asian Journal of Interdisciplinary Research in Marketing, 72(51), 205-224

Strauss, J. \& Frost, R. (2011). E-marketing (6 ${ }^{\text {th }}$ Ed.). New York: Pearson Education

Tsion, D. (2021). The effect of promotional mix practices on customer preference the case of five-star franchised hotels in Addis Ababa [Master Dissertation, St. Mary's University, South Sudan].

Ul-Abideeen, Z., \& Saleem, S. (2013). Effective advertising. European Journal of Business and Management, 3(3), 17-28

Wang, R., Xi, D., \& Liam, P. (2011). Analysis of the effect of sales promotion on customer patronage of mobile phone technologies in Shanghai, China. Asian Journal of Distance Learning, 56(20), 38-49

Yusuf, O. I. (2019). Comparative analysis of traditional and modern marketing communication systems for promoting hotels performance in Southwest, Nigeria [Doctoral dissertation, Ekiti State University, Ado-Ekiti].

Zawadi, C., \& Makena, W. (2019). Effect of social media marketing on the marketing performance of telecommunication firms in Kenya. International Journal of Innovation Research and Development, 7(3), 14-25 